\title{
Excitatory and Inhibitory Amino Acid Neurotransmitter Binding Sites in the Cerebellar Cortex of the Pigeon (Columba livia)
}

\author{
Roger L. Albin, Sharin Y. Sakurai*, Richard L. Makowiec and Sid Gilman \\ Department of Neurology, and *Neuroscience Program, University of Michigan, Ann Arbor, MI 48109, USA
}

\begin{abstract}
We used receptor autoradiography to determine the distribution of excitatory and inhibitory amino acid neurotransmitter binding sites in the cerebellar cortex of the pigeon (Columba livia). $\alpha$-Amino-3hydroxy-5-methylisoxazole-4-propionic acid, kainate and metabotropic binding sites had highest levels in the molecular layer. N-methyl-D-aspartate binding sites, assayed with both $\left[{ }^{3} \mathrm{H}\right] \mathrm{glutamate}$ under selective conditions and with $\left[{ }^{3} \mathrm{H}\right]$ glycine binding to the associated strychnine-insensitive glycine site, had highest levels in the granule cell layer. There was little specific binding of the non-competitive $\mathrm{N}$-methyl-D-aspartate antagonist, $\left[{ }^{3} \mathrm{H}\right] \mathrm{MK}-801$. The level of gamma-aminobutyric acid (GABA)-A binding sites was higher than GABA-B binding sites in both molecular and granule cell layers with the highest level of GABA-A sites in the granule cell layer. The highest level of GABA-B binding sites was in the molecular layer. $\left[{ }^{3} \mathrm{H}\right]$ Flunitrazepam binding levels were approximately the same in both molecular and granule cell layers. With the exception of kainate binding sites, the distribution of binding sites was identical to that seen in the cerebellar cortex of mammals. Our results support the concept that the chemoarchitecture of the cerebellar cortex has been conserved in the course of vertebrate evolution.
\end{abstract}

KEY WORDS: Glutamate Gamma-aminobutyric acid Cerebellum Avian Evolution

\section{INTRODUCTION}

Despite significant changes in size and external morphology (Nieuwenhuys, 1967), the neuronal circuitry of the cerebellar cortex has been remarkably conserved in the course of vertebrate evolution (Mugnaini, 1972; see Llinas and Hillman, 1969 for extensive review). This phylogenetic conservation of cerebellar cytoarchitecture and intrinsic connectional anatomy was first noted by Ramon y Cajal, who felt that the uniform organization of the cerebellar cortex across diverse vertebrate phyla amounted to a virtual 'biological law'. The climbing fibre-Purkinje cell and mossy fibre-granule cellparallel fibre-Purkinje cell circuits appear to exist in almost all vertebrates, and Golgi and ultrastructural studies indicate that the morphology of these synapses is relatively similar across vertebrate phyla (Llinas and Hillman, 1969). The presence of cerebellar cortical interneurons is more variable (Llinas and Hillman, 1969). Amphibians possess a sparse population of stellate cells, while reptiles possess both stellate and Golgi cells. Birds and mammals possess stellate, Golgi and basket cells.

Address correspondence to: Dr Roger L. Albin, Neuroscience Laboratory Building, 1103 E. Huron, Ann Arbor, MI 48109 USA.

0891-0618/91/060429-09 \$05.00

(c) 1991 by John Wiley and Sons Ltd
Electrophysiological studies of a variety of species have shown that the climbing fibre-Purkinje cell and parallel fibre-Purkinje cell synapses are excitatory (Llinas and Hillman, 1969). Similarly, the effect of interneurons is inhibitory in all species examined to date (Llinas and Hillman, 1969). The phylogenetic conservation of cerebellar cortical cytoarchitecture, synaptic morphology and synaptic electrophysiology suggests that the neurotransmitter/receptor chemoarchitecture of the cerebellar cortex may be similarly conserved across vertebrate phyla.

Recent studies of mammals have defined the neurotransmitters of cerebellar cortical neurons and their afferents. The neurotransmitter of mossy fibres, climbing fibres and granule cells is an excitatory amino acid (EAA; Beitz et al., 1986; Garthwaite et al., 1989; Somogyi et al., 1986; Foster and Roberts, 1983; Rea et al., 1983; Toggenburger et al., 1983; Wiklund et al., 1984; Kimura et al., 1985; Young et al., 1974; Hudson et al., 1976; Sandoval and Cotman, 1978; Stone,1979). Stellate, basket, Golgi and Purkinje cells use the inhibitory amino acid, gamma-aminobutyric acid (GABA; Madsen et al., 1985; Ottersen et al., 1988; Wuenschell et al., 1986). Both EAAs and GABA exert their effects through a variety of receptor subtypes. EAAs 
Table 1. GABA and EAA binding site assays

\begin{tabular}{|c|c|c|c|c|c|c|}
\hline Binding Site & Ligand & Conc (nM) & Buffer & Blockers & Blank & Reference \\
\hline $\mathrm{BDZ}$ & {$\left[{ }^{3} \mathrm{H}\right]$ Flunitrazepam } & 5 & $\begin{array}{l}50 \mathrm{~mm}- \\
\text { Tris-acetate, } \\
\text { pH } 7.4\end{array}$ & & $\begin{array}{l}5 \mu \mathrm{M}- \\
\text { Clonezepam }\end{array}$ & $\begin{array}{l}\text { Albin and Gilman } \\
\quad(1990)\end{array}$ \\
\hline GABA-A & {$\left[{ }^{3} \mathrm{H}\right] \mathrm{GABA}$} & 20 & $\begin{array}{l}50 \mathrm{mM}- \\
\text { Tris-Cl+ } \\
2.5 \mathrm{~mm}-\mathrm{CaCl}_{2}\end{array}$ & $100 \mu \mathrm{M}$-Baclofen & $\begin{array}{l}100 \mu \mathrm{M}- \\
\text { Isoguvacine }\end{array}$ & Chuetal. (1990) \\
\hline GABA-B & {$\left[{ }^{3} \mathrm{H}\right] \mathrm{GABA}$} & 20 & $\begin{array}{l}50 \mathrm{~mm}- \\
\text { Tris } \mathrm{Cl}+ \\
2.5 \mathrm{~mm}-\mathrm{CaCl}_{2}\end{array}$ & $10 \mu \mathrm{M}$-Isoguvacine & $\begin{array}{l}100 \mu \mathrm{M}- \\
\text { Baclofen }\end{array}$ & Chuet al. (1990) \\
\hline NMDA & {$\left[{ }^{3} \mathrm{H}\right]$ Glutamate } & 65 & $\begin{array}{l}50 \mathrm{~mm}- \\
\text { Tris-acetate, } \\
\text { pH } 7.4\end{array}$ & $\begin{array}{l}2.5 \mu \mathrm{M}- \\
\text { Quisqualate } \\
100 \mu \mathrm{M}-\mathrm{Kainate}\end{array}$ & $\begin{array}{l}1 \mu \mathrm{M}-\mathrm{NMDA} \\
\text { or } \\
100 \mu \mathrm{M}-\mathrm{CPP}\end{array}$ & $\begin{array}{l}\text { Makowiec et al. } \\
\qquad(1991)\end{array}$ \\
\hline Glycine & {$\left[{ }^{3} \mathrm{H}\right]$ Glycine } & 100 & $\begin{array}{l}50 \mathrm{~mm}- \\
\text { Tris-acetate, } \\
\text { pH } 7.4\end{array}$ & $1 \mu \mathrm{M}$-Strychnine & $1 \mu \mathrm{M}-$ Glycine & $\begin{array}{l}\text { McDonald et al. } \\
\quad(1990)\end{array}$ \\
\hline MK-801 & {$\left[{ }^{3} \mathrm{H}\right] \mathrm{MK}-801$} & 5 & $\begin{array}{l}50 \mathrm{~mm}- \\
\text { Tris-acetate, } \\
\text { pH } 7.4\end{array}$ & & $5 \mu \mathrm{M}-\mathrm{MK}-801$ & $\begin{array}{l}\text { Sakurai et al. } \\
\quad(1991)\end{array}$ \\
\hline AMPA & {$\left[{ }^{3} \mathrm{H}\right] \mathrm{AMPA}$} & 35 & $\begin{array}{l}50 \mathrm{mM}- \\
\text { Tris-Cl+ } \\
2.5 \mathrm{mM}-\mathrm{CaCl}_{2}+ \\
30 \mathrm{mM}-\mathrm{KSCN}\end{array}$ & & $1 \mu \mathrm{M}$-Glutamate & Nielsen et al.(1988) \\
\hline MET & {$\left[{ }^{3} \mathrm{H}\right]$ Glutamate } & 100 & $\begin{array}{l}\text { Tris } \mathrm{Cl}+ \\
2.5 \mathrm{mM}^{-\mathrm{CaCl}_{2}}+ \\
30 \mathrm{mM}-\mathrm{KSCN}\end{array}$ & $100 \mu \mathrm{M}-\mathrm{AMPA}$ & $\begin{array}{l}2.5 \mu \mathrm{M}- \\
\text { Quisqualate }\end{array}$ & Cha et al. (1990) \\
\hline Kainate & {$\left[{ }^{3} \mathrm{H}\right]$ Kainate } & 60 & $\begin{array}{l}50 \mathrm{mm-} \\
\text { Tris--acetate, } \\
\text { pH } 7.2\end{array}$ & & $100 \mu \mathrm{M}$-Kainate & $\begin{array}{l}\text { Wamsley et al. } \\
\text { (1982) }\end{array}$ \\
\hline
\end{tabular}

act through four generally recognized types of receptors, named after their selective agonists (Young and Fagg, 1990; Monaghan et al., 1989). aAmino-3-hydroxy-5-methylisoxazole-4-propionic acid (AMPA), kainate and N-methyl-D-aspartate (NMDA) receptors activate ion channels while the metabotropic (MET) receptor is coupled to inositol phospholipid metabolism. The NMDA receptor possesses a strychnine-insensitive binding site for glycine, and another binding site for the noncompetitive antagonists MK-80 l and phencyclidine. Gamma-aminobutyric acid receptors are divided into GABA-A receptors, linked to an inhibitory chloride channel and modulated by an associated benzodiazepine (BDZ) binding site (Enna, 1988), and GABA-B receptors, a G-protein-coupled receptor that modulates potassium and calcium channels (Bowery, 1989). To test the hypothesis that the neurotransmitter architecture of the cerebellar cortex has been conserved in the course of vertebrate evolution, we used receptor autoradiography to determine the distribution of EAA and GABA binding site subtypes in the cerebellar cortex of pigeons
(Columba livia). We compare our findings with previously published information on mammalian cerebellar cortex. The last common ancestor of avians and mammals is thought to have lived 320 million years ago (Carroll, 1988). Consequently, comparison of these two phyla provides a reasonable view of a large segment of vertebrate evolution. A preliminary account of this work has appeared (Albin et al., 1989).

\section{MATERIALS AND METHODS}

White Carneaux pigeons were purchased from Palmetto Farms (South Carolina). $\left[{ }^{3} \mathrm{H}\right]$ Glutamate, $\left[{ }^{3} \mathrm{H}\right]$ kainate, $\left[{ }^{3} \mathrm{H}\right]$ glycine, $\left[{ }^{3} \mathrm{H}\right] \mathrm{GABA}$ and $\left[{ }^{3} \mathrm{H}\right]$ flunitrazepam were purchased from Amersham (Arlington Heights, ILL). $\left[{ }^{3} \mathrm{H}\right] \mathrm{AMPA}$ and $\left[{ }^{3} \mathrm{H}\right] \mathrm{MK}$ 801 were purchased from DuPont-NEN (Boston, MA). Non-radioactive MK-801 was a gift of $\mathrm{Dr}$ L. L. Iversen (Merck, Sharp \& Dohme). Baclofen was a gift of Dr Peter Sorter (Ciba-Geigy). Nonradioactive AMPA, kainate, NMDA, quisqualate. 
3-(2-carboxypiperazin-4-yl)-propyl-1-phosphoric acid (CPP) and isoguvacine were purchased from CRB (Wilmington, DE). The remaining reagents were purchased from Sigma (St Louis, MO) and were of the highest possible purity.

After pigeons were decapitated, their brains were extracted rapidly from the cranial vault, covered in Lipshaw embedding matrix, and frozen in crushed dry ice. Brains were stored at $-70^{\circ} \mathrm{C}$ until the time of sectioning. After equilibration at $-20^{\circ} \mathrm{C}$, brains were sectioned in a coronal plane at 20 microns on a Lipshaw cryostat. Sections were thaw mounted onto gelatin-coated slides, air dried and stored at $-20^{\circ} \mathrm{C}$ until time of assay. All assays were performed within 3 days of sectioning.

EAA and GABA binding site subtypes were assayed according to standard techniques (Table 1). In all assays, non-specific binding is less than $10 \%$, except for MET binding, where non-specific binding approaches 50\%. GABA-A, GABA-B, NMDA, AMPA, MET, kainate and glycine binding sites were all assayed in a similar manner. Sections were prewashed in buffer at $4^{\circ} \mathrm{C}$ for $30 \mathrm{~min}$, dried under a stream of cool air and immersed in cytomailers containing buffer at $4^{\circ} \mathrm{C}$ with radioactive ligand and the required selective blocking agents. After a 45-min incubation period (except for $\left[{ }^{3} \mathrm{H}\right]$ glycine, with an incubation period of $35 \mathrm{~min}$ ), the sections received three (GABA assays) or four (remaining assays) rapid $4-\mathrm{ml}$ rinses of $4^{\circ} \mathrm{C}$ buffer followed by one (GABA assays) or two (remaining assays) rapid $3-\mathrm{ml}$ rinses of $2.5 \%$ glutaraldehyde in acetone at $4^{\circ} \mathrm{C}$, and dried under a stream of hot air.

MK-801 binding was assessed with the method of Sakurai et al. (1991, Table 1). Sections were prewashed in buffer for $30 \mathrm{~min}$, dried under a stream of cool air, and immersed in ligand solution containing $5 \mathrm{nM}\left[{ }^{3} \mathrm{H}\right] \mathrm{MK}-801$. Following incubation for $2 \mathrm{~h}$ at room temperature, sections were rinsed in buffer at $4^{\circ} \mathrm{C}$ for $80 \mathrm{~min}$, and dried under a stream of hot air. Sections were assayed simultaneously with sections of pigeon forebrain at levels where we have documented abundant $\left[{ }^{3} \mathrm{H}\right] \mathrm{MK}-801$ binding (Sakurai et al., 1990).

To measure $\mathrm{BDZ}$ binding site density, sections received $3 \times 10$-min washes in $4^{\circ} \mathrm{C}$ buffer, were dried under a stream of cool air, and immersed in $4^{\circ} \mathrm{C}$ ligand solution for $30 \mathrm{~min}$. Following incubation with ligand, sections received one quick dip in buffer at $4^{\circ} \mathrm{C}$ followed by $2 \times 5$-min rinses in buffer at $4^{\circ} \mathrm{C}$, and were dried under a stream of hot air.

Three pigeon brains were used for assay of GABA-A, GABA-B, BDZ and kainate binding, and three other brains were used for assay of MK801, NMDA, glycine, AMPA and MET binding sites. All assays were run in duplicate or triplicate. Following conclusion of the assays, the slides were apposed to tritium-sensitive film and exposed along with known radioactive standards for 10 days to 6 weeks (Table 1).
Table 2. GABA and EAA binding sites in pigeon cerebellar cortex. $N$ of three animals for each binding assay. All values in $\mathrm{fmol} / \mathrm{mg}$ protein (SEM)

\begin{tabular}{lcc}
\hline Receptor & Molecular layer & Granule cell layer \\
\hline BDZ & $331(27)$ & $440(6)$ \\
GABA-A & $695(32)$ & $2473(232)$ \\
GABA-B & $154(7)$ & $65(7)$ \\
Kainate & $23598(1200)$ & N.S. \\
AMPA & $1660(32)$ & $345(13)$ \\
MET & $673(166)$ & $198(56)$ \\
NMDA & $185(60)$ & $540(50)$ \\
MK-801 & $70(10)$ & $80(10)$ \\
GLY & $370(30)$ & $1500(90)$ \\
\hline
\end{tabular}

Films were developed in Kodak D-19 and binding site density in the molecular and granule cell layers was quantified with computer-assisted densitometry using the MCID system (Imaging Research, St Catherines, Ont.). It was impossible to determine reliably the extent of the Purkinje cell layer, and ligand binding in this layer was not measured. At least 50 readings were taken in each layer with a variable size cursor. Film density was converted to bound radioactivity with a polynomial regression curve derived from the co-exposed standards.

\section{RESULTS}

\section{GABA binding sites}

The overall level of GABA-A binding sites was higher than GABA-B binding sites in both granule cell and molecular layers (Table 2, Figure 1). There was a higher level of GABA-A binding sites in the granule cell layer than in the molecular layer. GABA-B binding sites had a higher level in the molecular layer than in the granule cell layer.

\section{BDZ binding sites}

$\mathrm{BDZ}$ binding sites had similar levels in both layers (Table 2, Figure 1).

\section{NMDA receptors}

When assayed with NMDA or CPP competition of $\left[{ }^{3} \mathrm{H}\right]$ glutamate binding, more NMDA binding sites were found within the granule cell layer than the molecular layer (Table 2, Figure 2). After NMDA or CPP competitive displacement of $\left[{ }^{3} \mathrm{H}\right]$ glutamate binding there was a significant amount of residual $\left[{ }^{3} \mathrm{H}\right]$ glutamate binding, particularly in the molecular layer (Figure 2). The amount of specific binding was identical regardless of whether NMDA or CPP were used to define non-specific binding. The pattern of $\left[{ }^{3} \mathrm{H}\right]$ glycine binding was identical to that of NMDA/ CPP competitive displacement of $\left[{ }^{3} \mathrm{H}\right]$ glutamate binding (Table 2, Figure 2), with more binding in the granule cell layer than the molecular layer. Little 


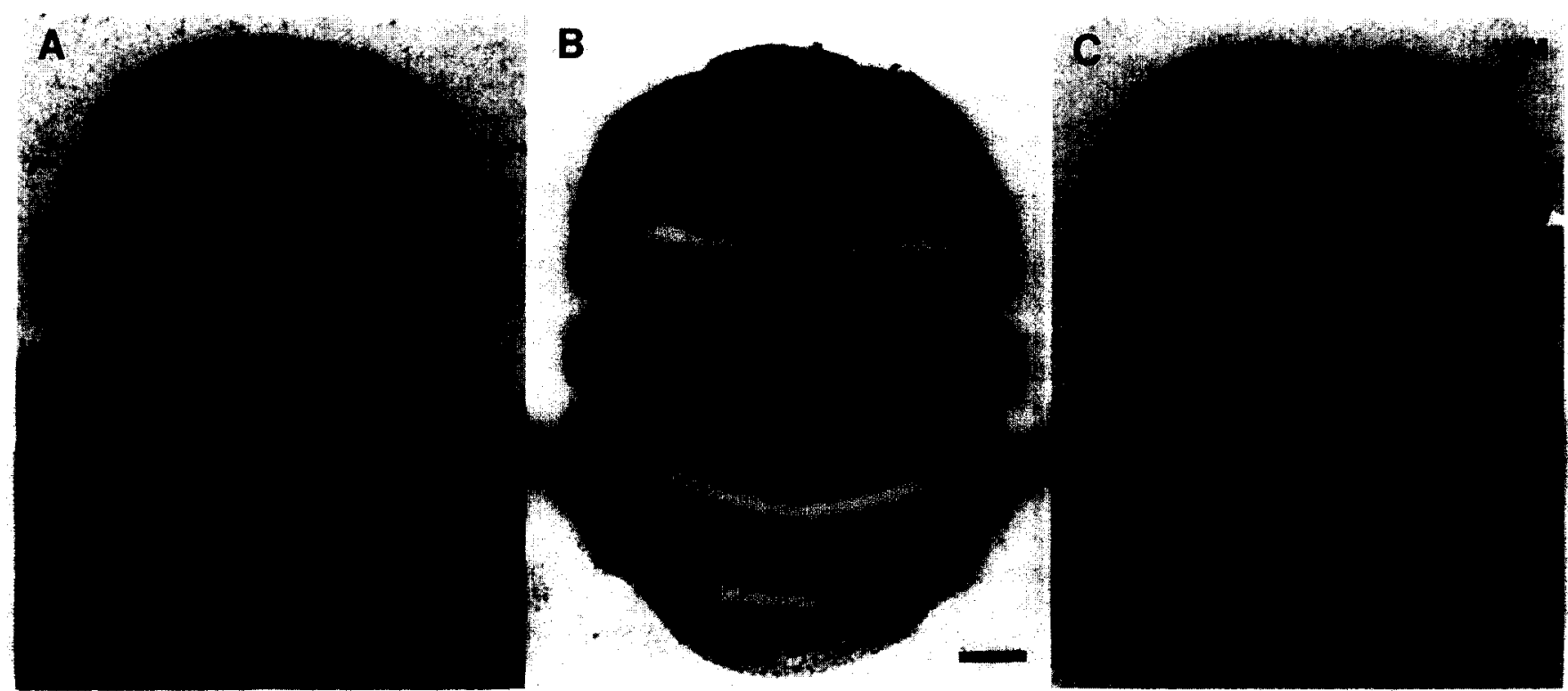

Fig 1. GABA and BDZ binding site distribution in pigeon cerebellar cortex. (A) BDZ binding sites; ligand binding levels are approximately equal in both molecular and granule cell layers. (B) GABA-A binding sites; ligand binding is highest in the granule cell layer (C) GABA-B binding sites; ligand binding is highest in the molecular layer. $\mathrm{ML}=$ molecular layer, $\mathrm{GL}=$ granule cell layer, scale bar $=0.88 \mathrm{~mm}$.

specific $\left[{ }^{3} \mathrm{H}\right] \mathrm{MK}-801$ binding was found in either layer of the cerebellar cortex (Table 2, Figure 2) while abundant specific $\left[{ }^{3} \mathrm{H}\right] \mathrm{MK}-801$ binding was found in sections of simultaneously assayed pigeon forebrain (data not shown).

\section{Non-NMDA EAA receptors}

AMPA, kainate and MET binding sites were found at highest level in the molecular layer (Table 2, Figure 3). Kainate binding sites had an exceptionally high level in the molecular layer with virtually no binding in the granule cell layer under these conditions.

\section{DISCUSSION}

\section{Methodological considerations}

Comparison of our present results with data obtained in mammals assumes that the binding site assays we employed identify identical sites in birds and mammals. Rigorous verification of this assumption would require an extensive series of pharmacological and kinetic experiments beyond the scope of this paper. Available evidence indicates that GABA-A, BDZ, AMPA and NMDA binding sites in avian brain are identical to those of mammals. Several groups have investigated the pharmacology, regulatory properties and kinetics of GABA-A and $\mathrm{BDZ}$ receptors in a broad variety of species (Dietl et al., 1988; Nielsen et al., 1978; Tehrani and Barnes,1986; Maggi et al., 1980). These properties have been found to be conserved across a broad range of species. Similarly, biochemical studies have shown that BDZ binding proteins in avians have physical properties similar to those of mammals (Hebebrand et al., 1986, 1987; Friedl et al., 1988). Henley and Barnard (1989) have found the pharmacology and kinetics of AMPA binding sites in chick brain homogenates to be similar to those described in mammals. Our own studies of NMDA receptor pharmacology, kinetics and regulation in pigeon brain (Sakurai et al., 1990) and those of McCabe and Horn (1988) in chick brain have shown that NMDA binding sites in avian brain have properties similar to those of mammals.

A different situation exists with respect to kainate binding sites. Our work confirms previous reports of a high density of kainate binding sites in the molecular layer of the avian cerebellum (Henke et al., 1981). In mammalian cerebellar cortex, $\left[{ }^{3} \mathrm{H}\right] \mathrm{kainate}$ binding is found mainly in the granule cell layer (Monaghan and Cotman, 1982; Unnerstall and Wamsley, 1983). In both mammals and birds, kainate binding sites exist in high and low affinity forms (Henke et al., 1981; Voukelatou et al., 1986; London et al., 1980). Henke et al. (1981) have documented that pigeon cerebellar cortical kainate binding is almost exclusively to the low affinity site. This binding protein has been purified and a monoclonal antibody directed against the kainate binding protein developed (Klein et al., 1988). Somogyi et al. (1990) have shown that this monoclonal antibody binds to cerebellar cortical glia. Cloning of the gene for the avian cerebellar kainate binding protein has also been accomplished and its sequence has relatively little resemblance to the rodent kainate receptor (Gregor et al., 1989). It seems unlikely that 


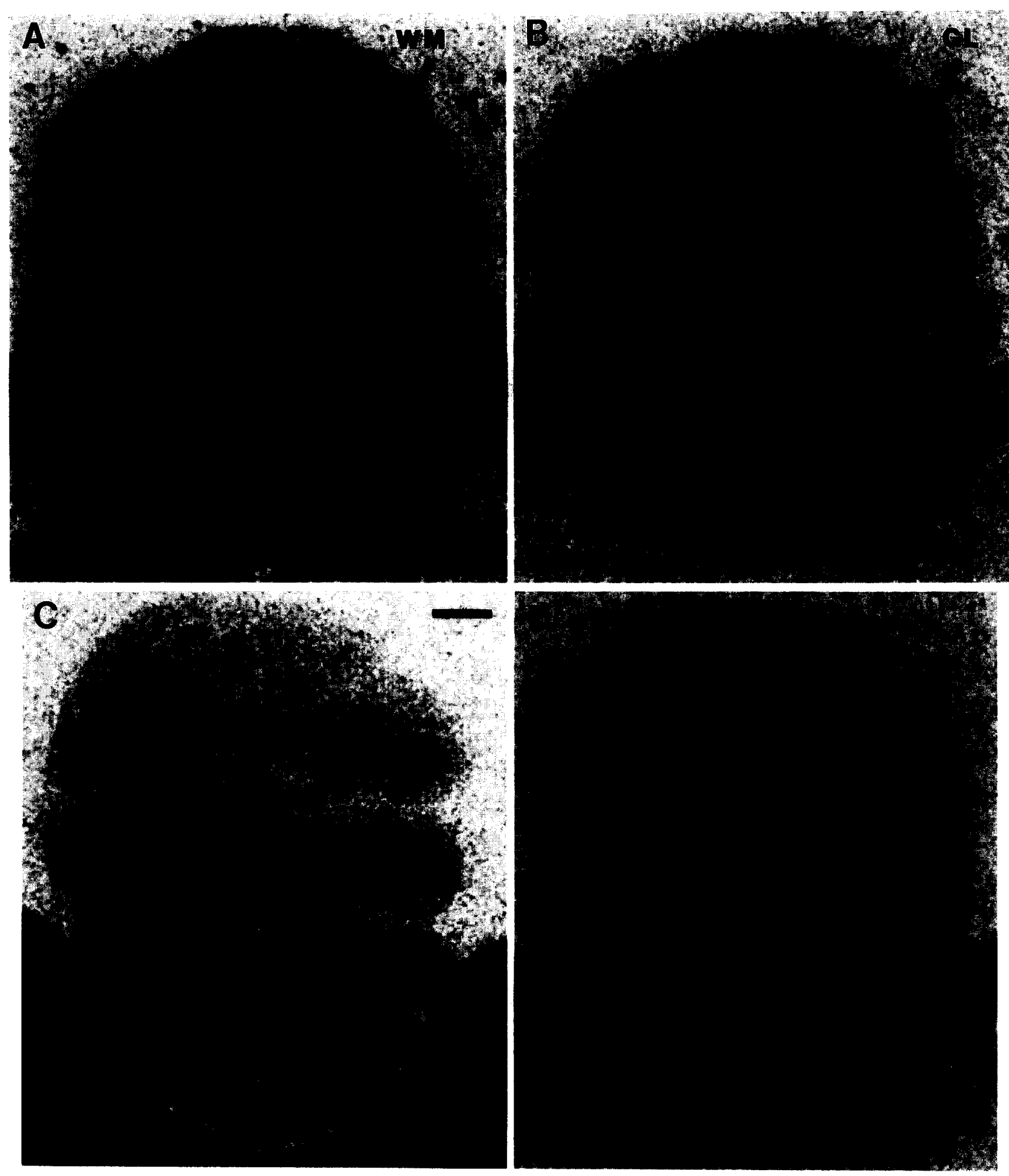

Fig 2. NMDA binding site distribution in pigeon cerebellar cortex. (A) [ $\left.{ }^{3} \mathrm{H}\right] \mathrm{Glutamate}$ binding in the absence of NMDA or CPP. (B) $\left[{ }^{3} \mathrm{H}\right]$ Glutamate binding in the presence of NMDA. Note the decrease in binding in the granule cell layer and the persistence of binding in the molecular layer. (C) Strychnine-insensitive glycine binding sites; ligand binding is highest in the granule cell layer, paralleling the distribution of [ $\left.{ }^{3} \mathrm{H}\right]$ glutamate binding that is competitively displaced by NMDA or CPP. (D) [ $\left.{ }^{3} \mathrm{H}\right] \mathrm{MK}-801$ binding; little binding is seen. Abbreviations and scale as in Fig. 1 .

kainate binding in the pigeon cerebellar cortex identifies a homologue of the mammalian neuronal kainate receptor.
Interpretation of receptor autoradiography with tritiated ligands is complicated by the existence of the so-called 'quenching phenomenon'. Tritium 

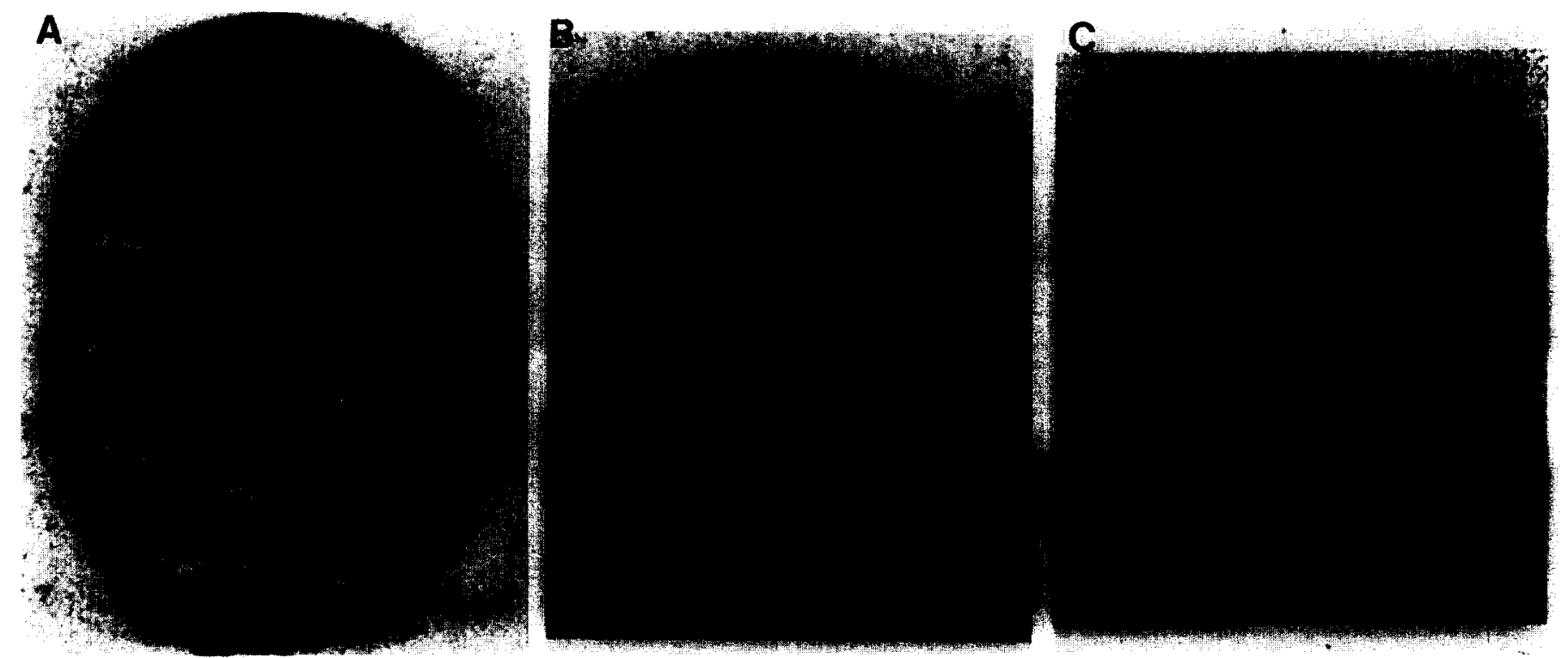

Fig 3. (A) Kainate binding sites; there is very high $\left[{ }^{3} \mathrm{H}\right] \mathrm{kainate}$ binding in the molecular layer. (B) AMPA binding sites; ligand binding is highest in the molecular layer. (C) MET binding sites; ligand binding is highest in the molecular layer. Image made by digital subtraction of non-specific binding from total binding because of the relatively high non-specific binding in the assay. Abbreviations and scale identical to those of Fig. 1 .

emits relatively weak beta particles and some of these particles are absorbed by surrounding tissue, especially white matter (Geary and Wooten, 1985; Geary et al., 1985; Rainbow et al., 1984). In the cerebellar cortex, this phenomenon may lead to an underestimate of the amount of ligand binding in the molecular layer relative to the granule cell layer. However, studies of $\left[{ }^{14} \mathrm{C}\right]$ glutamate binding in the rat pallidum and hippocampus show that white matter quenching does not cause a significant change in the pattern of binding site distribution (Greenamyre et al., 1987; McDonald et al., 1990), indicating that white matter quenching is not a major determinant of the qualitative distribution of binding sites. Finally, our experiments were all performed with single concentrations of ligands. We cannot, consequently, compare the absolute densities $\left(B_{\max }\right)$ of binding sites for different ligands. We can, however, determine the relative amounts of binding for a single ligand in the different layers of the cerebellar cortex. This analysis assumes only that the affinity $\left(K_{\mathrm{d}}\right)$ of binding sites for a given ligand is the same in both the granule cell and molecular layer.

\section{Comparison with mammals and other phyla}

In general, our results show that the distribution of GABA and EAA binding sites in pigeon cerebellar cortex is identical to that seen in mammals and those non-mammalian species that have been examined.

GABA-A binding site distribution has been well characterized in mammalian cerebellar cortex and in some non-mammalian species and found to be similar across a wide variety of species. In mammals, GABA-A binding sites are found in both molecular and granule cell layers with a significantly higher level of GABA-A binding sites in the granule cell layer (Palacios et al., 1980, 1981; Albin and Gilman, 1990). Schmitz et al. (1988), using $\left[{ }^{3} \mathrm{H}\right]$ muscimol as a GABA-A ligand, have obtained similar results in a variety of non-mammalian species including trout, toads and chickens. We have found also that turtle cerebellar cortex displays a similar distribution of GABA-A binding sites (Albin et al., 1989). Similarly, cerebellar cortical BDZ binding site distribution has also been well characterized in mammals and some non-mammalian species. In rodents, $\mathrm{BDZ}$ binding sites are found at highest level in the molecular layer while primates have a high level of $B D Z$ binding sites in both molecular and granule cell layers (Young and Kuhar, 1979; Palacios and Kuhar, 1982; Albin and Gilman, 1990). Dietl et al. (1988) and Schmitz et al. (1988) have both found that avians and some other non-mammalian species have roughly equal levels of $\mathrm{BDZ}$ binding sites in the molecular and granule cell layers. Our present data in pigeons, obtained with a different GABA-A ligand and an identical BDZ binding site assay, confirm previous results.

No prior study has reported the distribution of GABA-B binding sites in a non-mammalian species. In both rodent and human cerebellar cortex, GABA-B binding sites are found predominantly in the molecular layer (Chu et al., 1990; Bowery et al., 1987; Albin and Gilman, 1990). Our data in pigeons reveal an identical pattern of GABA-B binding site distribution and density relative to GABA-A binding sites. There may be one important difference in GABA-B binding site distribution between mammals and birds. In the vermis of the rat cerebellar cortex, we have shown that GABA-B binding 
sites are arranged in alternating high and low density parasagittal zones (Albin and Gilman, 1989), a pattern similar to the well-characterized parasagittal distribution of olivocerebellar fibres and other markers of parasagittal zonation in the cerebellar cortex. Freedman et al. (1977) have shown that the olivocerebellar system in pigeons has a parasagittal termination pattern similar to that seen in mammals. We found, however, no evidence of parasagittal zonation of GABA-B binding sites in the pigeon cerebellar cortex. Study of more mammals and non-mammalian species will be necessary to determine if the absence of parasagittal zonation of GABA-B binding sites in pigeon cerebellum is a significant inter-phyletic difference.

The distribution of NMDA binding sites in pigeon cerebellar cortex appears also to be identical to that of mammals. When assayed with either $\left[{ }^{3} \mathrm{H}\right]$ glutamate under selective conditions or with $\left[{ }^{3} \mathrm{H}\right]$ glycine, the highest density of NMDA binding sites is found in the granule cell layer in both mammals and pigeons (Olson et al., 1987; Greenamyre et al., 1985; Monaghan and Cotman,1985; McDonald et al., 1990; Makowiec et al., 1991). Our data confirm previous $\left[{ }^{3} \mathrm{H}\right]$ glutamate binding data obtained in chick brain by Mitsacos et al. (1990), who used less selective assays. As previously documented by Henley and Barnard (1989) in chick brain, the density of $\left[{ }^{3} \mathrm{H}\right] \mathrm{MK}-801$ binding was relatively low, despite the presence of a moderate density of NMDA binding sites. This phenomenon is also seen in mammals, where the binding site for MK-801 and related ligands is found in the cerebellar cortex but in a low affinity state (Vignon et al., 1986; Sakurai et al., 1991). Our $\left[{ }^{3} \mathrm{H}\right]$ glutamate/NMDA assay reveals also a high level of $\left[{ }^{3} \mathrm{H}\right]$ glutamate binding in the molecular layer that is not competitively displaced by NMDA or CPP. Since this assay is done in the presence of high concentrations of kainate and quisqualate, this residual binding is insensitive to kainate or quisqualate competition. Preliminary experiments (Albin et al., unpublished data) have shown that this residual binding is competitively displaced by glutamate. This non-NMDA, nonkainate, non-quisqualate glutamate binding site exists also in human and rat molecular layer and appears to be located on neurons (Albin and Gilman, 1990; Higgins et al., 1989; Greenamyre et al., 1990).

Binding to non-NMDA EAA binding sites in pigeon cerebellar cortex is also largely similar to that seen in mammals, where AMPA and MET binding occur at highest levels in the molecular layer (Makowiec et al., 1990, 1991; Cha et al., 1990; Nielsen et al., 1988). As mentioned above, $\left[{ }^{3} \mathrm{H}\right]$ kainate binding in avian cerebellar cortex has a different distribution from that seen in mammals and available evidence indicates that this binding protein is not homologous to the kainate receptor of mammals. It is intriguing that the only binding assay that gives a pattern of binding different from that seen in mammals is also the only one where the avail- able evidence indicates lack of homology between mammalian and avian binding proteins. This counter-example supports the idea, originally put forward by Deitl and Palacios (1988), that use of binding site assays developed in mammals provides a legitimate basis for comparison of neurotransmitter chemoarchitecture when similar binding site distributions are found in homologous structures.

Finally, experiments in rodents using toxic, viral or genetic lesions of cerebellar cortical neuron subpopulations have allowed assignment of specific binding site types to cerebellar cortical neurons (reviewed in Albin and Gilman, 1990). GABA-A, $\mathrm{BDZ}$ and NMDA binding sites are found on granule cells, while AMPA, MET, GABA-B and BDZ binding sites are found on Purkinje cell dendrites. The identity of distribution of GABA and EAA binding sites between mammals and pigeons suggests that the cellular localization of these binding sites is also phylogenetically conserved. There is no direct evidence in avians to confirm this hypothesis, but it is consistent with electrophysiological data showing that climbing and parallel fibre activation in both birds, reptiles and mammals produces very similar patterns of post-synaptic potentials in Purkinje cells (Llinas and Hillman, 1969).

In summary, our data support the conclusion that the chemoarchitecture of the cerebellar cortex is conserved in the course of vertebrate evolution.

\section{ACKNOWLEDGEMENTS}

We thank Drs Tony Reiner and James Woods for the donation of pigeon brains, and Richard Price for assistance with figure preparation. This work was supported by NS 01300 and NS 19613.

\section{REFERENCES}

Albin, R. L. and Gilman, S. (1989). Parasagittal zonation of GABA-B receptors in molecular layer of rat cerebellum. Eur. J. Pharm. 173, 113-114.

Albin, R. L. and Gilman, S. (1990). Autoradiographic localization of inhibitory and excitatory amino acid neurotransmitter receptors in human normal and olivopontocerebellar atrophy cerebellar cortex. Brain Res. 522, 37-45.

Albin, R. L., Richfield, E. K., Reiner, A., Young, A. B. and Penney, J. B. (1989). Autoradiographic localization of amino acid neurotransmitter receptors in the cerebellar cortex of pigeon (Columba livia) and turtle (Pseudemys scripta). Soc. Neurosci. Abstr. 15, 407.

Beitz, A. J., Larson, A. A., Monaghan, P., Altschuler, R. A., Mullett, M. M. and Madl, J. E. (1986). Immunohistochemical localization of glutamate, glutaminase and aspartate aminotransferase in neurons of the pontine nuclei of the rat. Neuroscience 17, 741-753.

Bowery, N. (1989). GABA-B receptors and their significance in mammalian pharmacology. TIPS 10, 401-407.

Bowery, N. G., Hudson, A. L. and Price, G. W. (1987). GABA-A and GABA-B receptor site distribution in rat central nervous system. Neuroscience 20, 365-383. 
Carroll, R. L. (1988). Vertebrate Paleontology and Evolution. W.H. Freeman, New York.

Cha, J.J., Makowiec, R. L., Penney, J. B. and Young, A. B. (1990). L- $\left[{ }^{3} \mathrm{H}\right]$ Glutamate labels the metabotropic excitatory amino acid receptor in rodent brain. Neurosci. Lett. $113,78-83$.

Chu, D. C. M., Albin, R. L., Young, A. B. and Penney, J. B. (1990). Distribution and kinetics of GABA-B binding sites in rat central nervous system: a quantitative autoradiographic study. Neuroscience 34, 341-358.

Dietl, M. and Palacios, J. M. (1988). Receptor autoradiography as a tool for the study of the phylogeny of the basal ganglia. J. Recept. Res. 8, 521-532.

Dietl, M. M., Cortes, R. and Palacios, J. M. (1988). Neurotransmitter receptors in the avian brain. III. GABA-benzodiazepine receptors. Brain Res. 439, 366-371.

Enna, S. J. (1988). GABA-A Receptors. In $G A B A$ and Benzodiazepine Receptors (ed. Squires, R. F.), pp. 91-106. CRC Press, Boca Raton, Florida.

Foster, G.A. and Roberts, P. J.(1983). Neurochemical and pharmacological correlates of inferior olive destruction in the rat: attenuation of the events mediated by an endogenous glutamate-like substance. Neuroscience 8 , 277-284.

Freedman, S. L., Voogd, J. and Vieloye, G. J. (1977) Experimental evidence for climbing fibers in the avian cerebellum. J. Comp. Neurol. 175, 243-252.

Friedl, W., Hebebrand, J., Rabe, S. and Propping, P. (1988). Phylogenetic conservation of the benzodiazepine binding sites: pharmacological evidence. Neuropharmacology 27 (2), 163-170.

Garthwaite, J. and Brodbelt, A. R. (1989). Synaptic activation of N-methyl-D-aspartate and non- $\mathrm{N}$-methyl-Daspartate receptors in the mossy fibre pathway in adult and immature rat cerebellar slices. Neuroscience 29, $401-412$

Geary, W. T., Toga, A. W. and Wooten, G. F. (1985). Quantitative film autoradiography for tritium: methodological considerations. Brain Res. 337, 99-108.

Geary, W. A. and Wooten, G. F. (1985). Regional tritium quenching in quantitative autoradiography of the central nervous system. Brain Res. 336, 334-336.

Greenamyre, J. T., Penney, J. B., Young, A. B., Hudson, C., Silverstein, F. S. and Johnston, M. V. (1987). Evidence for transient perinatal glutamatergic innervation of globus pallidus. J. Neuroscience 7: 1022-1030.

Greenamyre, J. T., Higgins, D. S., Young, A. B. and Penney, J. B. (1990). Regional ontogeny of a unique glutamate recognition site in rat brain: an autoradiographic study. Int. J. Dev. Neurosci. 8, 437-445.

Greenamyre, J. T., Olsen, J. M. M., Penney, J. B. and Young, A. B. (1985). Autoradiographic characterization of N-methyl-D-aspartate-, quisqualate- and kainate-sensitive glutamate binding sites. J. Pharmacol. Exp. Ther. 233, 254-263.

Gregor, P., Mano, I., Maoz, I., McKeown, M. and Teichberg, V. I. (1989). Molecular structure of the chick cerebellar kainate-binding subunit of a putative glutamate receptor. Nature 343, 689-692.

Hebebrand, J., Friedl, W., Kessler, K., Hewing, M. and Propping, P. (1987). Further characterization of the avian benzodiazepine receptor subunits including phyloand ontogenetic aspects. J. Neurochem. 49, 1888-1893.

Hebebrand, J., Friedl, W., Unverzagt, B. and Propping, P. (1986). Benzodiazepine receptor subunits in avian brain. $J$. Neurochem. 47, 790-793.
Henke, H., Beaudet, A. and Cuenod, M. (1981). Autoradiographic localization of specific kainic acid binding sites in pigeon and rat. Brain Res. 219, 95-105.

Henley, J. M. and Barnard, E. A. (1989). Solubilisation and characterisation of a putative quisqualate-type glutamate receptor from chick brain. J. Neurochem. 53, 140-148.

Henley, J. M., Moratello, R., Hunt, S. P. and Barnard, E. A. (1989). Localization and quantitative autoradiography of glutamatergic ligand binding sites in chick brain. Eur. J. Neurosci. 1, 516-523.

Higgins, D. S., Greenamyre, J. T., Young, A. B. and Penney, J. B. (1989). A unique glutamate site in an autoradiographic assay. Soc. Neurosci. Abstr. 15, 1163.

Hudson, D. B., Valcana, T., Bean, G. and Timiras, P. S. (1976). Glutamic acid: a strong candidate as the neurotransmitter of the cerebellar granule cell. Neurochem. Res. 1: 73-81.

Kimura, H., Okamoto, K. and Sakai, Y. (1985). Pharmacological evidence for L-aspartate as the neurotransmitter of cerebellar climbing fibres in the guinea-pig. $J$. Physiol. 365, 103-119.

Klein, A. U., Niederoest, B., Winterhalter, K. H., Cuenod, M. and Streit, P. (1988). A kainate binding protein in pigeon cerebellum: purification and localization by monoclonal antibody. Neurosci. Lett. 95, 359-364.

Llinas, R. and Hillman, D. E. (1969). Physiological and morphological organization of the cerebellar circuits in various vertebrates. In Neurobiology of Cerebellar Evolution and Development (ed. Llinas, R.), pp. 43-76. American Medical Association, Chicago.

London, E. D., Klemm, N. and Coyle, J. T. (1980). Phylogenetic distribution of $\left[{ }^{3} \mathrm{H}\right] \mathrm{kainic}$ acid receptor binding sites in neuronal tissue. Brain Res. 192, 463-476.

Madsen, S., Ottersen, O. P. and Storm-Mathisen, J. (1985). Immunocytochemical visualization of taurine neuronal localization in the rat cerebellum. Neurosci. Lett. 60, 255-260.

Maggi, A., Satinover, J., Oberdorfer, M., Mann, E. and Enna, S. J. (1980). Phylogenetic characteristics of muscimol-activated benzodiazepine receptor binding Brain Res. Bull. 5, 167-171.

Makowiec, R. L., Albin, R. L., Cha, J.-H. J., Young, A. B and Gilman, S. (1990). Two types of quisqualate receptors are decreased in human olivopontocerebellar atrophy cerebellar cortex. Brain Res. 523, 309-312.

Makowiec, R. L., Cha, J. J., Penney, J. B. and Young, A. B. (1991). Characterization of cerebellar excitatory amino acid binding sites in normal, granuloprival, and purkinje cell deficient mice. Neuroscience, in press.

McCabe, B. J. and Horn, G. (1988). Learning and memory: regional changes in $\mathrm{N}$-methyl-D-aspartate receptors in the chick brain after imprinting. Proc. Natl. Acad. Sci. USA 85, 2849-2953.

McDonald, J. W., Johnston, M. V. and Young, A. B (1990). Differential ontogenetic development of three receptors comprising the NMDA receptor/channel complex in the rat hippocampus. Exp. Neurol. 110, 237-247.

McDonald, J. W., Penney, J. B., Johnston, M. V. and Young, A. B. (1990). Characterization and regional distribution of strychnine-insensitive $\left[{ }^{3} \mathrm{H}\right]$ glycine binding sites in rat brain by quantitative receptor autoradiography. Neuroscience 35, 653-668.

Mitsacos, A., Dermon, C. R., Stassi, K. and Kouvelas, E. D. (1990). Localization of L-glutamate binding sites in chick brain by quantitative autoradiography. Brain Res. 513, 348-352. 
Monaghan, D. T., Bridges, R. J. and Cotman, C. W. (1989). The excitatory amino acid receptors: Their classes, pharmacology, and distinct properties in the function of the central nervous system. Annu. Rev. Pharmacol. Toxicol. 29, 365-402.

Monaghan, D. T. and Cotman, C. W. (1982). The distribution of $\left[{ }^{3} \mathrm{H}\right]$ kainic acid binding in rat $\mathrm{CNS}$ as determined by autoradiography. Brain Res. 252, 91-100.

Monaghan, D. T. and Cotman, C. W. (1985). Distribution of $\mathrm{N}$-methyl-D-aspartate-sensitive $\mathrm{L}-\left[{ }^{3} \mathrm{H}\right]$ glutamatebinding sites in rat brain. J. Neurosci. 5, 2909-2919.

Mugnaini, E. (1972). The histology and cytology of the cerebellar cortex. In The Comparative Anatomy and Histology of the Cerebellum: The Human Cerebellum, Cerebellar Connections, and Cerebellar Cortex, (eds Larsell, O. and Jansen, J.), pp. 201-264. The University of Minnesota Press, Minneapolis.

Nielsen, E. O., Cha, J. J., Honore, T., Penney, J. B. and Young, A. B. (1988). Thiocyanate stabilizes AMPA binding to the quisqualate receptor. Eur. J. Pharmacol. 157, 197-203.

Nielsen, M., Braestrup, C. and Squires, R. F. (1978). Evidence for a late evolutionary appearance of brain-specific benzodiazepine receptors: an investigation of 18 vertebrate and 5 invertebrate species. Brain Res. 141, 342-346.

Nieuwenhuys, R. (1967). Comparative anatomy of the cerebellum. Prog. Brain. Res. 25, 1-93.

Olson, J. M. M., Greenamyre, J. T., Penney, J. B. and Young, A. B. (1987). Autoradiographic localization of cerebellar excitatory amino acid binding sites in the mouse. Neuroscience 22, 913-923.

Ottersen, O. P., Madsen, S., Storm-Mathisen, J., Somogyi, P., Scopsi, L. and Larsson, L.-I. (1988). Immunocytochemical evidence suggests that taurine is colocalized with GABA in the Purkinje cell terminals, but that the stellate cell terminals predominantly contain GABA: A light- and electron microscopic study of the rat cerebellum. Exp. Brain Res. 72, 407-416.

Palacios, J. M. and Kuhar, M. J. (1982). Ontogeny of high-affinity GABA and benzodiazepine receptors in the rat cerebellum: an autoradiographic study. Dev. Brain Res. 2, 531-539.

Palacios, J. M., Wamsley, J. K. and Kuhar, M. J. (1981). High affinity GABA receptors - autoradiographic localization. Brain Res. 222, 285-307.

Palacios, J. M., Young, W. S. and Kuhar, M. J. (1980). Autoradiographic localization of gammaaminobutyric acid (GABA) receptors in the rat cerebellum. Proc. Natl. Acad. Sci. USA 77, 670-674.

Rainbow, T. C., Bigeon, A. and Berck, D. J. (1984). Quantitative receptor autoradiography with tritiumlabeled ligands: comparison of biochemical and densitometric measurements. J. Neurosci. Meth. 11, 231-241.

Rea, M. A., McBride, W. J. and Rohde, B. H. (1980). Regional and synaptosomal levels of amino acid neurotransmitters in the 3-acetylpyridine deafferentated rat cerebellum. J. Neurochem. 34 (5), 1106-1108.

Sakurai, S. Y., Albin, R. L., Reiner, A. and Young, A. B. (1990). $\left[{ }^{3} \mathrm{H}\right] \mathrm{MK}-801$ binding in pigeon forebrain. Soc. Neurosci. Abstr. 16, 90.

Sakurai, S. Y., Cha, J. J., Penney, J. B. and Young, A. B. (1991). Regional distribution and properties of $\left[{ }^{3} \mathrm{H}\right] \mathrm{MK}-801$ binding sites determined by quantitative autoradiography in rat brain. Neuroscience, 40, 533-543.
Sandoval, M. E. and Cotman, C. W. (1978). Evaluation of glutamate as a neurotransmitter of cerebellar parallel fibers. Neuroscience 3, 199-206.

Schmitz, E., Reichelt, R., Walkowiak, W., Richards, J. G. and Hebebrand, J. (1988). A comparative phylogenetic study of the distribution of cerebellar GABA-A benzodiazepine receptors using radioligands and monoclonal antibodies. Brain Res. 473, 314-320.

Somogyi, P., Eshhar, N., Teichberg, V. I. and Roberts, J. D. (1990). Subcellular localization of a putative kainate receptor in Bergmann glial cell using a monoclonal antibody in the chick and fish cerebellar cortex. Neuroscience 35, 9-30.

Somogyi, P., Halasy, K., Somogyi, J., Storm-Mathisen, J. and Ottersen, O.P. (1986). Quantification of immunogold labelling reveals enrichment of glutamate in mossy and parallel fibre terminals in cat cerebellum. Neuroscience 19, 1045-1050.

Stone, T. W. (1979). Glutamate as the neurotransmitter of cerebellar granule cells in the rat: electrophysiological evidence. Br. J. Pharmacol. 66, 291-296.

Tehrani, M. H. J. and Barnes, E. M. (1986). Ontogeny of the GABA receptor complex in chick brain: studies in vivo and in vitro. Dev. Brain Res. 25, 91-98.

Toggenburger, G., Wiklund, L., Henke, H. and Cuenod M. (1983). Release of endogenous and accumulated exogenous amino acids from slices of normal and climbing fibre deprived rat cerebellar slices. $J$. Neurochem. 41, 1606-1613.

Unnerstall, J. R. and Wamsley, J. K. (1983). Autoradiographic localization of high-affinity $\left[{ }^{3} \mathrm{H}\right]$ kainic acid binding sites in the rat forebrain. Eur.J Pharmacol. 86, 361-371

Vignon, J., Privat, A., Chaudieu, I., Thierry, A. Kamenka, J.-M. and Chicheportiche, R. (1986) $\left[{ }^{3} \mathrm{H}\right]$ Thienyl-phencyclidine $\left(\left[{ }^{3} \mathrm{H}\right] \mathrm{TCP}\right)$ binds to two different sites in rat brain. Localization by autoradiographic and biochemical techniques. Brain Res. 378, 133-141.

Voukelatou, G., Angelatoy, F. and Kouvelas, E. D. (1986). The binding properties and regional ontogeny for $\left[{ }^{3} \mathrm{H}\right]$ glutamatic acid $\mathrm{Na}^{+}$-independent and $\left[{ }^{3} \mathrm{H}\right]$ kainic acid binding sites in chick brain. Int. J. Devel. Neurosci. 4, 339-352.

Wiklund, L., Toggenburger, G. and Cuenod, M. (1984). Selective retrograde labelling of the rat olivocerebellar climbing fiber system with $D-\left[{ }^{3} \mathrm{H}\right]$ aspartate. Neuroscience 13, 441-468.

Wuenschell, C. W., Fisher, R. S., Kaufman, D. L. and Tobin, A. J. (1986). In situ hybridization to localize mRNA encoding the neurotransmitter synthetic enzyme glutamate decarboxylase in mouse cerebellum. Proc. Natl. Acad. Sci. USA 83, 6193-6197.

Young, A. B. and Fagg, G. E. (1990). Excitatory amino acid receptors in the brain: membrane binding and receptor autoradiographic approaches. TIPS 11, 126-133.

Young, A. B., Oster-Granite, M. L., Herndon, R. M. and Snyder, S. H. (1974). Glutamic acid: selective depletion by viral-induced granule cell loss in hamster cerebellum. Brain Res. 73, 1-13.

Young, W. S. and Kuhar, M. J. (1979). Autoradiographic localization of benzodiazepine receptors in the brains of humans and animals. Nature 280, 393-395. 